\title{
Hydrogen as Fuel and Its Impacts on Environment
}

\author{
Selahattin Gültekin ${ }^{1,2}$ \\ 1. Chemical Engineering Department, Kyrgyz-Turkish Manas University, Bishkek 720038, Kyrgyzstan \\ 2. Department of Bioengineering, Uskudar University, Istanbul 34662, Turkey
}

\begin{abstract}
Energy consumption per capita is a kind of indication of the development for a society. Energy sources, today, are mainly fossil fuels (coal, oil and natural gas) which can cause severe environmental problems such as acid rains, global warming and climate changes. In addition to severe environmental problems, the sources of fossil fuels are finite. Because of increasing need of energy, researchers are forced to search for renewable energy sources such as hydro, biomass, wind, solar, geothermal, wave, tide and so on. Hydrogen $\left(\mathrm{H}_{2}\right)$ seems to be more promising for a clean energy source. In fact, it is a clean energy carrier with a role to save environment. It does also reduce the emission of greenhouse gases by using it as a fuel in fuel cells or in internal combustion engines directly. For usage of $\mathrm{H}_{2}$ as fuel, it is necessary either to compress or to liquefy it. Both processes are difficult and costly. Metallic and nonmetallic hydrides have received considerable research interest in recent years. $\mathrm{NaBH}_{4}$ is the one of the most prospective $\mathrm{H}_{2}$ storage materials as it stores 10.8 weight \% hydrogen. $\mathrm{H}_{2}$ is generated by hydrolysis reaction of $\mathrm{NaBH}_{4}$ in the presence of a suitable catalyst. Another important fact with fuel cells is that the 2nd law of thermodynamics is bypassed so that no thermal efficiency limitations are imposed. In this paper, adverse effects of fossil fuels and positive effects of fuel cells on environment are emphasized.
\end{abstract}

Key words: Fuel cells, Carnot cycle, environmental pollution, metal hydrides.

\section{Introduction}

$\mathrm{H}_{2}$ is universally accepted as a clean energy carrier because of its high energy density. It does also reduce the emission of greenhouse gases by using it as a fuel in fuel cells or in internal combustion engines directly [1, 2].

Hydrogen energy is a clean energy and has no environmental problem. Fossil fuels, however, produce air pollutants and greenhouse gases. Therefore, the usage of fossil fuel must be minimized.

The main drawbacks of the fossil fuels are multi-fold:

(1) They are in limited amount on the globe and in the next 50 years or so they will, most likely, be depleted [3].

(2) They also contain S- and N- heterocompounds which are eventually converted to $\mathrm{SO}_{2}$ and $\mathrm{NO}_{x}$ acid gases upon burning. These gases are then converted $\mathrm{SO}_{3}$ and $\mathrm{NO}_{2}$ in the atmosphere. These gases react

Corresponding author: Selahattin Gültekin, professor, research fields: chemical reaction engineering and thermodynamics. with $\mathrm{H}_{2} \mathrm{O}$ vapor in the atmosphere and are converted to $\mathrm{H}_{2} \mathrm{SO}_{4}$ and $\mathrm{HNO}_{3}$, respectively. At the end, these acids precipitate as so-called acid rains [4]. Acid rains are not only harmful for human beings, animals and plants, but they are also disaster for the environment.

(3) Generation of $\mathrm{CO}_{2}$ upon burning of fossil fuels. $\mathrm{CO}_{2}$ is the main contributor of the greenhouse gases, which causes global warming and climate changes [5, 6].

As can be understood from the above discussions that fossil fuels are not environmentally friendly due to $\mathrm{SO}_{2}, \mathrm{NO}_{x}$ and $\mathrm{CO}_{2}$ gas generations after burning.

Acid rain by itself is another important issue. In this paper the focus will be on "the effect of $\mathrm{CO}_{2}$ on the global warming and climate changes and how to minimize $\mathrm{CO}_{2}$ emission to atmosphere" by means of chemical reactions and physical processes [7, 8].

\section{Description}

\subsection{Remedy}

Since all the fossil fuels eventually produce $\mathrm{CO}_{2}$, consumption of them must be minimized if not 
eliminated totally. For this reason, alternative energy sources must be sought worldwide [9, 10].

Fossil fuels have been powering the industrial development since the beginning. The environmental pollution, however, has reached such high levels that it became a serious threat to plants, wild life and human health. For example, air pollution causes asthma and cancer as well as some other serious diseases.

The technology of renewable energy must be improved so that the percentage of renewable energy in the total energy consumption should be increased. Solar, wind, geothermal as well as biomass are becoming extremely promising. Especially $\mathrm{H}_{2}$ energy is recently attracting more attention than ever before.

\subsection{Hydrogen $\left(H_{2}\right)$ Energy}

Technically, to use $\mathrm{H}_{2}$ as a fuel, it is necessary either to compress the gas to a small volume or to liquefy it. Both processes are highly difficult and costly owing to the chemical and physical properties of hydrogen. Compared with these traditional hydrogen storage processes, metallic and nonmetallic hydrides have also received considerable research interest in recent years. $\mathrm{NaBH}_{4}$ is the one of the most prospective hydrogen storage materials as it stores 10.8 weight \% hydrogen. In addition to its high hydrogen storage capability, it is also nonflammable, non-toxic in nature and stable in alkaline solutions. Hydrogen is generated by the following hydrolysis reaction of $\mathrm{NaBH}_{4}$ in the presence of a suitable catalyst:

$$
\mathrm{NaBH}_{4}+2 \mathrm{H}_{2} \mathrm{O} \rightarrow \mathrm{NaBO}_{2}+4 \mathrm{H}_{2}
$$

As can be seen, half of the hydrogen produced comes from the water which is a great advantage and make it effective on-board hydrogen generation method for portable proton-exchange membrane fuel cells applications [11]. The reaction product, borate, is environmentally friendly and can be recycled for the further production of $\mathrm{NaBH}_{4}$.

If $\mathrm{H}_{2}$ is used in fuel cells, the 2nd law of thermodynamics is by-passed, hence the efficiency is not limited by Sadi Carnot cycle. So in this case, a higher efficiency is obtained as compared to the conventional mode which is:

Chemical energy $\rightarrow$ heat energy $\rightarrow$ mechanical energy $\rightarrow$ electrical energy

There are, as can be seen, a few intermediate steps, hence lower efficiencies.

By using fuel cell, however, it is possible to convert the chemical energy directly into electrical energy:

$$
\text { Chemical energy } \rightarrow \text { electrical energy }
$$

In this case, Carnot cycle limitations are by-passed [12]. For this reason, the future of fuel cells is very bright and $\mathrm{H}_{2}$-economy will probably dominate in near future [13].

\section{Conclusions}

(1) Use of more efficient fossil fuel cycles and cogeneration system in electricity production is inevitable.

(2) It should be understood that climate change is not local, but a global problem.

(3) Nowadays, intensive studies have been carried out on hydrogen energy. If some problems in hydrogen technology are overcome, many things will change in human beings life. Hydrogen will replace petroleum. By using hydrogen in fuel cell, electric energy can be produced with a high efficiency up to $60 \%$ (with cogeneration, this could go to $80 \%$ ).

\section{Acknowledgments}

The author would like to express his thanks to Kyrgyz-Turkish Manas University for its support.

\section{References}

[1] Gültekin, S., Al-Zakri, A. S., Al-Saleh, M. A., Celiker, H., and Schnurnberger. 1995. "Experimental Studies and Electrochemical Parameters of Raney-Silver Gas Diffusion Electrode in Hydrogen-Oxygen Fuel Cell.” Arabian J. for Science and Eng. 20 (4): 635-47.

[2] Çengel, A. Y., and Boles, M. A. 2014. Thermodynamics: An Engineering Approach, 8th ed., McGraw-Hill.

[3] Ecotricity. 2018. "The End of Fossil Fuels.” Accessed November 1, 2018. https://www.ecotricity.co.uk/our-green-energy/energy-ind 
ependence/the-end-of-fossil-fuels.

[4] Satterfield, C. N., and Gültekin, S. 1982. "Effect of Hydrogen Sulfide on Catalytic Hydrodenitrogenation of Quinoline.” Ind. Eng. Des. and Dev. 20 (1): 62-8.

[5] Hansen, J., Sato, M., Ruedy, R., Lacis, A., and Oinas, V. 1997. "Global Warming in Twenty-First Century: An Alternative Scenario.” Proc. Natl. Acad. Sci. 18: 9875-80.

[6] Halmann, M. M., and Steinberg, M. 1999. Greenhouse Gas Carbon Dioxide Mitigation: Science and Technology. Lewis Publishers, Boca Raton.

[7] Herzog, H. J., and Drake, E. M. 1996. "Carbon Dioxide Recovery and Disposal from Large Energy Systems.” Annual Review of Energy and Environment 21: 145-66.

[8] Bachu, S. 2000. "Sequestration of $\mathrm{CO}_{2}$ in Geological Media: Criteria and Approach for Site Selection in
Response to Climate Change Energy Con.” Manna. 41: 953-70.

[9] Gentzis, T. 2000. "Subsurface Sequestration of Carbon Dioxide-An Overview from an Alberta (Canada) Perspective.” Int. J. Coal Geol. 43: 287-305.

[10] Kruger, P. 2006. Alternative Energy Sources: The Quest for Sustainable Energy. John Wiley \& Sons, Inc.

[11] Spiegel, C. 2008. PEM Fuel Cell: Modeling and Simulation Using MATLAB. John Wiley \& Sons, Inc.

[12] Smith, J. M., Van Ness, H., and Abbott, M. 2004. Introduction to Chemical Engineering Thermodynamics, 7th ed., McGraw-Hill.

[13] Bell, M., and Wietschel, M. 2009. The Hydrogen Economy-Opportunities and Challenges. Cambridge University Press. 